\title{
OPEN Author Correction: iTRAQ-based quantitative analysis reveals proteomic changes in Chinese cabbage (Brassica rapa L.) in response to Plasmodiophora brassicae infection
}

\author{
Mei Lan, Guoliang Li, Jingfeng Hu, HongliYang, Liqin Zhang, Xuezhong Xu, Jiajia Liu, \\ Jiangming He \& Rifei Sun
}

Correction to: Scientific Reports https://doi.org/10.1038/s41598-019-48608-0, published online 19 August 2019

In the original version of the Article, in Figure 4, the names of the differentially expressed proteins were outdated and have now been corrected to the international gene names.

Additionally, in the Supplementary Figures S2, S3 and S4 originally published with this Article, the names of the differentially expressed proteins were incorrect.

These errors have now been corrected in the PDF and HTML versions of the article, and in the Supplementary Figure files that accompany the Article.

\begin{abstract}
(c) (i) Open Access This article is licensed under a Creative Commons Attribution 4.0 International License, which permits use, sharing, adaptation, distribution and reproduction in any medium or format, as long as you give appropriate credit to the original author(s) and the source, provide a link to the Creative Commons license, and indicate if changes were made. The images or other third party material in this article are included in the article's Creative Commons license, unless indicated otherwise in a credit line to the material. If material is not included in the article's Creative Commons license and your intended use is not permitted by statutory regulation or exceeds the permitted use, you will need to obtain permission directly from the copyright holder. To view a copy of this license, visit http://creativecommons.org/licenses/by/4.0/.
\end{abstract}

(C) The Author(s) 2020 